\title{
IN MEMORIAM: PROFESSOR HJ ERASMUS 10 January 1935 - 15 June 2016
}

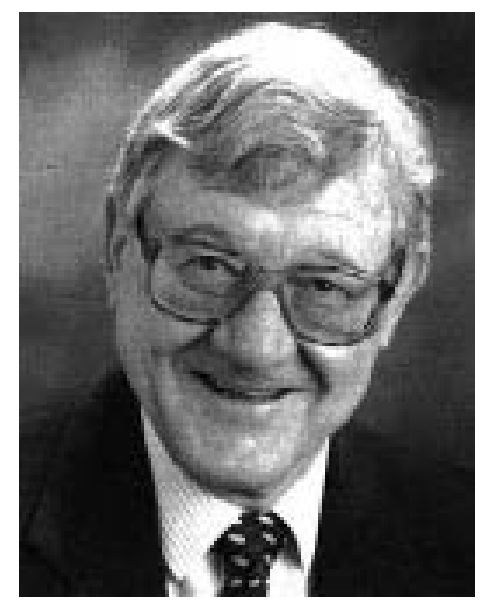

Prof Hennie Erasmus

It is with great sadness that we heard of the passing away of Hendrik Jacobus Erasmus on 15 June 2016, an esteemed member of the Editorial Board of Fundamina and a frequent contributor of legal historical contributions to this legal journal.

Hennie Erasmus was a man of many talents. He had a formidable reputation as academic, as author, as judge, and as historian. He was born on 10 January 1935 in Ladysmith, Natal. After matriculation at the Kroonstad High School in 1952, he obtained the degrees BA and MA (both cum laude) from the University of the Free State, followed by an LLB from the University of South Africa and a DLitt et Phil (cum laude) from Leiden. 
His academic career involved both Classics and the Law. After earlier appointments as Professor of Latin at the University of the Free State, and Professor of Classics at the University of Port Elizabeth, Hennie was appointed as Professor of Law at the University of South Africa in 1974. Between 1974 and 1976 Stellenbosch University took the brave step of appointing three ultramontani (or more correctly, north of the Hex River mountain) as Professors of Law, with Hennie Erasmus undoubtedly the most illustrious of the three. Hennie Erasmus, his wife Maureen and their three children, Nico, Hannchen and Christian, were firmly rooted in Stellenbosch and Hennie made substantial contributions to the Law Faculty. He served the Faculty with great distinction for almost two decades, including positions as Dean, during which period he was instrumental in securing the HF Oppenheimer Chair in Human Rights Law for the Faculty sponsored by Anglo American, and as Visiting Professor at the University of Florida in the United States, until his retirement in 1995. Many thousands of students attended his classes on the law of civil procedure and of succession, all of whom had great affection and appreciation for Hennie both as teacher and as role model. His colleagues shared these sentiments as is evidenced by a tribute on the faculty's website which stated among other things: "Hennie Erasmus personified the values of collegiality, modesty and excellence."

Hennie Erasmus was the leading expert on the law of civil procedure in his day. He authored (and co-authored) standard works in the field, such as Jones and Buckle - The Civil Practice of the Magistrates' Courts in South Africa and his magnum opus, Superior Court Practice. The latter work is still cited in practice simply as "Erasmus" - even though Hennie has handed over the reins to younger authors many years ago. In addition, he contributed numerous articles to law journals over the years and contributed significantly to law reform as member of and special consultant to the Rules Board for Courts of Law, and as a member of its Civil Justice Reform Committee.

His most recent articles on civil procedure are "Judicial case management and the adversarial mindset - the New Namibian rules of court" and "Judicial review of inferior court proceedings - or, the ghost of the prerogative writs in South African law" published in the 2015 numbers of the Journal of South African Law (TSAR). His articles in Fundamina include among others: "The beginnings of a mixed system; or, advocates at the Cape Bar during the early nineteenth century" (2015); "Circuit courts in the Cape Colony during the nineteenth century: Hazards and achievements" (2013); "Land 'Jobbing' by British Officials in the Orange River Sovereignty" (2011); and "Title to land and loss of land in the Griqua Captaincy of Philippolis, 1826-1861" (2010). An erudite article with the title "Natural law: Voet's criticism of De Groot" is published in this volume of Fundamina. He also contributed an important chapter to the volume of essays published in A Man of Principle: The Life and Legacy of JC de Wet with the title "Die Koopkontrak en Aediliese Aksies" (2013). Most recently he co-authored a book titled Employment 
Relations Management Back to Basics: A South African Perspective published by LexisNexis in 2015. All of these contributions were thoroughly researched and written in Hennie's characteristic lucid and concise style.

After his retirement as professor and a stint at the Cape Bar, Hennie's legal career entered a new dimension with his appointment as a judge of the Western Cape High Court with effect from 1 May 2002. As a judge he commanded wide respect, as exemplified by a recent letter to Die Burger by a former student, a State advocate, who described Hennie as "'n ware heer" wat " binne en buite die die hof presies dieselfde mens was, altyd hoflik, vriendelik en nederig".

Hennie Erasmus retired from the Bench in 2010 after reaching the statutory retirement age of 75 , but for him retirement simply meant shifting to another gear, because he did not believe in becoming idle. He conducted the odd private arbitration, but more importantly, he re-kindled his links with the Law Faculty of Stellenbosch by accepting appointments as extraordinary professor and research fellow in the Department of Private Law. This afforded him the opportunity to revive his interest in legal history, and especially the early history of legal practice in South Africa. This resulted in an impressive list of articles in academic journals such as Fundamina as mentioned above and the splendid article in the South African Journal of Cultural History (2012) titled "The Underwood \& Underwood stereographs of the AngloBoer War, 1899-1902".

This tribute would be incomplete without mention of his wife Maureen. Hennie and Maureen met when they were in standard 7 at school in Kroonstad in the Free State. They have been married for fifty eight years and throughout this time Maureen was Hennie's loyal life partner and pillar of strength.

To Hennie, the Classical scholar, we say, as did the Roman poet Catullus to his late brother:

Atque in perpetuum frater ave atque vale - And forever, brother, hail and farewell.

Ben Griesel, former Judge of the Western Cape High Court, and Cornie van der Merwe, Senior Research Fellow, University of Stellenbosch 